IBIMA Publishing

Journal of Enterprise Resource Planning Studies

http://www.ibimapublishing.com/journals/JERPS/jerps.html

Vol. 2016 (2016), Article ID 331270, 21 pages

DOI: $10.5171 / 2016.331270$

Research Article

\title{
Reinventing ERP Life Cycle Model: From Go-Live To Withdrawal
}

\author{
Tingting Huang and Kazuhiko Yasuda
}

School of Economics and Management, Tohoku University, Sendai, Miyagi, Japan

Correspondence should be addressed to: Tingting Huang; yoruhuang@gmail.com

Received date: 10 November 2014; Accepted date: 10 February 2015; Published date: 4 January 2016

Academic Editor: Tomislav Rozman

Copyright (C) 2016. Tingting Huang and Kazuhiko Yasuda. Distributed under Creative Commons CC-BY

4.0

\begin{abstract}
The aims of this research are to clear the definition of ERP life cycle and to propose a conceptual ERP life cycle model through a new approach. This research adopts literature survey and theoretical inference as major methodology. We conclude that most of researches about ERP life cycle have an inaccurate understanding and misuse of this term. The findings of this research will shift people's focus from traditional ERP life cycle to the real ERP life cycle-the post-implementation phase, since the ERP implementation is getting easier as well as entrance of new types of ERP. The conceptual model of ERP life cycle consists of the Diffusion stage, the Utilization stage, the Enhancement stage, and the Decline stage. Besides analyzing related previous researches, we also introduce two major dimensions (Organization and System) consisting of five criteria (Governance, Participation, Skills, Cost Efficiency, and Scope \& Architecture) to construct a strict conceptual model. It will be the basis of the researches on ERP post-adoption and be valued to both academic and practical world. In order to verify and revise the conceptual model of ERP Life Cycle, we will keep focusing and analyzing every stage of the ERP Life Cycle model in the future works, especially, the final stage which has no data and needs to be paid more attentions to.
\end{abstract}

Keywords: Enterprise Resource Planning (ERP), ERP Life Cycle Model, Post-implementation, Go-Live

Cite this Article as: Tingting Huang and Kazuhiko Yasuda (2016), "Reinventing ERP Life Cycle 


\section{Introduction}

Enterprise Resource Planning (ERP) emerged two decades ago and has become one of the most important parts in organizations. As a dominant ERP package vendor, SAP (Systemanalyse und Programmentwicklung) has completely consolidated its position in 1990s based on the $\mathrm{R} / 3$ system. During the past years, the ongoing improvement of the $\mathrm{R} / 3$ system has been taken in order to catch up with the development of Information and Communication Technology (ICT) in both software and hardware, and also to respond the need of its customers which are always facing turbulent marketing situation (Holland and Light, 1999) such as Bell, Pump, Chemical, Threads, Statco and Pharmco, etc. On the other hand, ERP system as software not only has attracted companies' attention for many years, but also researchers' one, since it can integrate a variety of discrete resources and functions into the businesses management. Within the studies of ERP, Catersels et al., (2010) pointed out that the ERP implementation and the ERP model are two major domains of ERP researches, of which three different models can be found in the latter: data models, Critical Success Factor (CSF) models and phase models. The phase model is the ERP Life Cycle model.

In practical world, especially ten years before, there were few organizations that had re-implemented the second ERP system after the first one. In other words, the ERP system is supposed to live as long as the organizations exist.
The main reason is the numerous costs of implementation. Meanwhile, with the technological development during the past twenty years, the ERP also had been changed significantly. No need for enormous money, time, and people to implement ERP system as before. Even implementation itself will not be necessary since the cloud ERP comes (Kiadehi and Mohammadi, 2012). According to the Enterprise IT (Information Technology) Trends Survey by Japan Users Association of Information Systems (JUAS) in 2008, 70\% of the enterprises had introduced the ERP system for less than ten years, and only $8 \%$ had been using the same ERP system for more than twenty-one years. The average life time of ERP system in an enterprise is only fourteen years (Harada, 2008). This means that $70 \%$ of the enterprises will face the ending of their ERP systems in five years.

The aims of this research are clear the definition of ERP life cycle and to propose a conceptual ERP life cycle model through a new approach. In this paper, we suggest that we need to shift our focus from traditional ERP life cycle to the real ERP life cycle-the post-implementation phase since the ERP implementation is getting easier and cheaper and new types of ERP system, such as SaaS and cloud ERP, are spreading rapidly. What is happening within the organizations after the implementation of ERP system? How to verify the health condition of an operating ERP system? How far the ERP system can go? What should the organizations do if the ending (changing) comes? To answer these questions, it is important to understand

Tingting Huang and Kazuhiko Yasuda (2016), Journal of Enterprise Resource Planning Studies, Article ID 331270, DOI: 10.5171/2016.331270 
more about the situation after the implementation, especially, the last period of the ERP life time. Hence, as the ultimate step of an exploratory research trilogy, this paper focuses on fundamental concept of ERP Life Cycle, which is considered to be the preparation for the researches about the final stage of ERP Life Cycle. This research adopts literature survey and theoretical inference as major methodology.

The outline of this paper will be the following. In the next section, main issues of traditional ERP Life Cycle will be mentioned. Then, a new definition of ERP Life Cycle will be proposed; the necessity of the redefinition will be discussed too. In the section three, the process of reinventing the conceptual model of ERP Life Cycle will be discussed in detail. In the section four, a conceptual model of ERP Life Cycle will be proposed with specific explanation. Finally, conclusion and a few of future works will be listed.

\section{Rethinking ERP Life Cycle}

\section{Confusion on Concept \& Focus}

In order to get a thorough understanding about ERP life cycle theory, Yasuda and Huang (2014) first redefined 'life cycle' along with authoritative dictionaries as:"The sequence of events which repeats from birth (beginning) to death (ending) in every generation of living (non-living) things that distinguishes itself as being related to a period of development.". There are four factors, Maturation, Stages, Generation, and Self, which should be contained at the same time by any concept of ' $X$ Life Cycle' (' $X$ ' means any research object. e.g. Product Life Cycle).

(1) The first one is 'Maturation', for example, going from one stage to another, beginning with one state and ending with another, indicating that this is a process which happens over particular period of time.

(2) Second, 'Stages'. The words such as 'series of forms', 'sequence of stages', and 'sequence of events', are used to stress the point that there will be some kind of regular pattern during the period of time, and this should be presented as 'Stages'.

(3) 'Generation' means the same process would be repeated afterwards, not only once. This is the main factor that discriminates the concept of Life Cycle from the concept of Life Span and Life Course, which are usually treated as exchangeable (O'Rand and Kcreker, 1990).

(4) Finally, 'Self'. There is also one subtext behind the word of life cycle: the main subject must be the living (non-living) thing itself. When we talk about the life cycle of animal, the birth means newborn outside its parent's body as an individual. Similarly, the life cycle of non-living thing means the non-living thing itself is the main subject, which should not include the time of becoming itself.

For the purpose of knowing the current status of research on ERP life cycle, in

Tingting Huang and Kazuhiko Yasuda (2016), Journal of Enterprise Resource Planning Studies, Article ID 331270, DOI: 10.5171/2016.331270 
the research of Huang and Yasuda (2014), 26 models of traditional ERP life cycle which are considered to be original models were collected and discussed. However, we have not yet found a clear definition of ERP Life Cycle in previous researches. That's the reason why we try to find some helps in other field by analyzing the concept of Life Cycle. To get a more clear vision, we made a comprehensive comparison in Table 1. According to the above definition, the Stages factor and the Generation factor are the ones that all the 26 models reach the standard appropriately. They all have certain phases or stages to describe the life of ERP system. Looking at the Maturation factor, they all have a start and an end. However, we can find in Table 1, the ends are not the same. Some end before the post-implementation phase, and some end during the middle of the post-implementation phase. Although all of them start from the pre-implementation phase, the pre-implementation phase is a decision-making phase, which means that the ERP system does not exist yet. Clearly, the Self factor does not be met. Based on the analysis of life cycle theories in other three fields (Yasuda and Huang, 2014), ERP life cycle should start at the point that the ERP is used in organization for the first time, not like the traditional ERP life cycle which was influenced by IS/ASP life cycle. The reasons are also been explained in the same research (Huang and Yasuda, 2014).
Clearly, researches on ERP systems have focused mainly on initial implementation activities, and paid little attention to ongoing use and upgrades, particularly the phase after that (Brehm and Markus, 2000). According to the previous studies, the ERP Life Cycle in organization can remain for more than twenty years. On the other hand, within the twenty years, three years-the longest-for implementation is still less than the one fifth of the operation time. Further, new types of ERP software, such as cloud ERP, SaaS (Software as a Service), etc., are rising. ERP systems should now enter an era of relatively "easy configuration" that takes days and weeks with implementation completed in weeks, or at most 2-3 months (Jacobs and 'Ted' Weston Jr, 2007). This process is more common in the Small and Medium Enterprises (SMEs) nowadays. However, the studies around ERP Life Cycle are still focus on the pre-implementation and the implementation phase. The traditional ERP life cycle models which still focus on the phases before go-live cannot reflect the real situation of those new types of ERP as well. That is the reason why it is necessary to rethink the definition of ERP life cycle. With all the confusions around ERP Life Cycle, we could not help but to ask: What is an ERP Life Cycle? What happens in the seventeen years, which is supposed to benefit most from the ERP system, is still mistiness to the academic world (Mäkipää, 2003; Rosemann, 2000). It is time to focus on the real ERP Life Cycle.

Tingting Huang and Kazuhiko Yasuda (2016), Journal of Enterprise Resource Planning Studies, Article ID 331270, DOI: 10.5171/2016.331270 
Table 1: Comprehensive Comparison between the Conceptual Model and the Traditional ERP Life Cycle

\begin{tabular}{|c|c|c|c|c|c|c|}
\hline \multirow[b]{2}{*}{$\begin{array}{c}\text { ERP Irmplementation } \\
\text { Course }\end{array}$} & \multicolumn{2}{|c|}{ Conceptual Model of ERP Life Cycle } & \multirow[t]{2}{*}{ Diffusion } & Utilization & Enhancement & \multirow[t]{2}{*}{ Decline } \\
\hline & Pre-Implementation & Implementation & & \multicolumn{2}{|c|}{ Post-Implementation } & \\
\hline $\begin{array}{l}\text { Bancroft et al. } \\
\text { (1996) }\end{array}$ & Focus & $\begin{array}{l}\text { Create the As Is picture } \\
\text { Create of the To To be design; } \\
\text { Construction and Testing: } \\
\text { Actual lmplementat on }\end{array}$ & & & & \\
\hline $\begin{array}{l}\text { Ross } \\
(1998)\end{array}$ & Design & \multicolumn{2}{|l|}{ Implementation } & Stabilizing & $\begin{array}{l}\text { Continuous } \\
\text { inproyement: } \\
\text { Pransformation. }\end{array}$ & \\
\hline $\begin{array}{c}\text { Esteves\&Pastor } \\
\text { (1999) }\end{array}$ & $\begin{array}{l}\text { Adoption } \\
\text { Dacision }\end{array}$ & \multicolumn{2}{|l|}{ Implementation } & $\begin{array}{l}\text { Use \& } \\
\text { Maintenance }\end{array}$ & Evolution & Retirement \\
\hline $\begin{array}{l}\text { Markuss } 1 \text { Tanis } \\
(2000)\end{array}$ & Project Chartering & The project & Shakedown & \multicolumn{2}{|c|}{ Onward \& Upward } & \\
\hline $\begin{array}{l}\text { Parr\&Shanks } \\
\text { (2000) }\end{array}$ & Planning & \multicolumn{2}{|l|}{ Project } & \multicolumn{2}{|c|}{ Enhancement } & \\
\hline $\begin{array}{l}\text { Shanks et al. } \\
(2000)\end{array}$ & Planning & \multicolumn{2}{|l|}{ Implementation } & Stablization & Improvement & \\
\hline $\begin{array}{c}\text { Rosemann, } \\
(2000)\end{array}$ & $\begin{array}{ll}\text { Business } & \text { System } \\
\text { Engingeering } & \text { Selection }\end{array}$ & \multicolumn{2}{|c|}{ System Implementation } & \multicolumn{2}{|c|}{ System Use and Chang } & \\
\hline $\begin{array}{c}\text { Changkgable } \\
(2000)\end{array}$ & Pro-Implementation & \multicolumn{2}{|l|}{ Implementation } & \multicolumn{2}{|c|}{ Post-Implementation } & \\
\hline$\underset{(2000)}{\text { Brehm \&Markus }}$ & $\begin{array}{l}\text { Vendor's Cycle:Analysis; Design; } \\
\text { Coding \& Test Releasese. } \\
\text { Adopter's Cycle: Concopt. }\end{array}$ & $\begin{array}{l}\text { Adopter's Cycle: } \\
\text { Contguration }\end{array}$ & $\begin{array}{l}\text { Adcopter's Cycle: } \\
\text { Rollout }\end{array}$ & \multicolumn{2}{|c|}{$\begin{array}{l}\text { Adopter's Cycle: } \\
\text { Usage }\end{array}$} & \\
\hline $\begin{array}{l}\text { Shields } \\
(2001)\end{array}$ & Pre-Project & \multicolumn{3}{|c|}{ Project Implementation } & Post-Project & \\
\hline $\begin{array}{c}\text { Stefanou } \\
(2001)\end{array}$ & $\begin{array}{l}\text { ERP } \\
\text { selection }\end{array}$ & \multicolumn{2}{|c|}{ ERP implementation } & \multicolumn{2}{|c|}{$\begin{array}{l}\text { ERP operation } \\
\text { /maintenancelevolution }\end{array}$} & \\
\hline $\begin{array}{l}\text { Ahituv ot al. } \\
\text { (2002) }\end{array}$ & Selection Definition & \multicolumn{2}{|l|}{ Implementation } & & Operation & \\
\hline $\begin{array}{l}\text { Dibbern et al. } \\
(2002)\end{array}$ & Acquisition & Implementation & & Stabilization & $\begin{array}{l}\text { Opcration \& } \\
\text { Improvement }\end{array}$ & \\
\hline $\begin{array}{c}\text { Măkipäă } \\
(2003)\end{array}$ & Initiation; Evaluation; Selection; & $\begin{array}{l}\text { Modification/Business } \\
\text { Process Reengineering/ } \\
\text { Conversion of Data; ralaning: }\end{array}$ & Go-Live & Termination & $\begin{array}{l}\text { Exploitation and } \\
\text { Development }\end{array}$ & \\
\hline $\begin{array}{l}\text { Bajwa et al. } \\
(2004)\end{array}$ & Awareness:Selection:Preparation: & Implementation & & & peration & \\
\hline $\begin{array}{l}\text { Ehie\&Madsen } \\
\text { (2005) }\end{array}$ & $\begin{array}{ll}\text { Project } & \text { Eusiness } \\
\text { Preparation } & \text { Elueprint }\end{array}$ & $\begin{array}{ll}\text { Realizaion } & \begin{array}{l}\text { Final } \\
\text { Preparation }\end{array}\end{array}$ & & So Live and Supp & & \\
\hline $\begin{array}{l}\text { Klee } \\
(2005)\end{array}$ & Product Evaluation & Implement Phase & $\begin{array}{l}\text { Implement } \\
\text { Phasell \& } \\
\text { Beyond }\end{array}$ & $\begin{array}{l}\text { Extending } \\
\text { Value }\end{array}$ & $\begin{array}{l}\text { Maintaining } \\
\text { Value }\end{array}$ & $\begin{array}{l}\text { Declining } \\
\text { Value }\end{array}$ \\
\hline $\begin{array}{l}\text { Aloini et al. } \\
\text { (2007) }\end{array}$ & Pre-Implementation & Implementation & & Post-Im & pplementation & \\
\hline $\begin{array}{l}\text { Peslak et al. } \\
(2007)\end{array}$ & Preparation and Training & Transition & Performance & and Usefulness & Maintenance & \\
\hline $\begin{array}{c}\text { Souza\&zyicker } \\
(2009)\end{array}$ & Decision \& Selection & Implementation & Stabilization & & ilization & \\
\hline $\begin{array}{l}\text { Law et al. } \\
\text { (2010) }\end{array}$ & Initiation & Contagion & Con & & Integration & \\
\hline 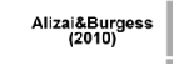 & Pre-Planning; Planning & $\begin{array}{l}\text { Setup \&Re-engineer, System Design; } \\
\text { Configuration \& Tesing, } \\
\text { Installation \& Go live. }\end{array}$ & & & & \\
\hline $\begin{array}{l}\text { Dantes\&Hasibuan } \\
\text { (2011) }\end{array}$ & $\begin{array}{l}\begin{array}{l}\text { Project } \\
\text { preparation, selannology }\end{array} \text { Project } \\
\text { formulation }\end{array}$ & Impimentation \& Develooment & & Post-Implement: & tation & \\
\hline 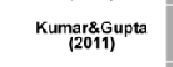 & Project Planning & $\begin{array}{l}\text { Gap Aralysis, Reergineering, Con- } \\
\text { figuration Implimentaation Team } \\
\text { Iraining, Iesting, End usar Iraining }\end{array}$ & Go-Live & Post-Imp & olementation & \\
\hline $\begin{array}{l}\text { Hasibuan\&Dantes } \\
(\text { (2012) }\end{array}$ & $\begin{array}{l}\text { Project } \\
\text { preparation, sechnology }\end{array}$ & Impimentation/Development & & Deployment & & \\
\hline $\begin{array}{l}\text { Bento\& Costa } \\
\text { (2013) }\end{array}$ & Selection/Acquisition & Implementation/Use & & Sta: & ibilization & Declining \\
\hline
\end{tabular}

\section{Redefine ERP Life Cycle}

As one kind of Information Systems, Enterprise Resource Planning (ERP) system has many definitions and descriptions. Davenport (1998) describes the enterprise systems to be dreamy "commercial software packages promise the seamless integration of all the information flowing through a company-financial and accounting information, human resource information, supply chain information, customer information". Deloitte Consulting (1999) describes it as "a packaged business software system that allows a company to automate and integrate the majority of its business processes, share common data and practices across the entire enterprise, and produce and access information in a real-time environment". In O'Leary's 
book (O'Leary, 2000), ERP systems are "computer-based systems designed to process an organizations transactions and facilitate integrated and real-time planning, production, and customer response". Although with various emphases, the ERP itself means ERP system, and it is a solution of organization embodies in the form of application software package with numerous characteristics. Hence, according to the new definition of life cycle, ERP Life Cycle can be redefined as: "the period of the substantial ERP system's development which repeats from Go-Live to withdrawal with distinguishing stages in every generation."

Looking at the main events around an ERP project in organization, it can be divided into three phases admittedly (Figure 1), ERP Pre-implementation phase, ERP Implementation phase, and ERP Post-implementation phase (Bento and Costa, 2013; Chang and Gable, 2000). In the first phase, a decision will be made by top managers about whether or not to introduce an ERP system into the organization. If the answer is yes, a precise plan needs to be discussed. When choosing to customize an ERP system, you will face needs definition, design, planning, etc., just like the SDLC (Software or Systems Development Life Cycle); ERP is being developed during this phase. If the off-the-shell ERP system is selected, you may need to find a consultant partner, estimate benefits, etc. In any case, you will need to select the ERP vendor, estimate the investment and risks, deal with the contracts, and prepare the infrastructure, etc. which all should be considered as activities of the ERP Design.

Next, in the Implementation phase, the installation phase per se, the ERP system will be installed into the hardware of organization by following specific implementation procedures. For a homemade system, this phase will be considered to start at coding, testing, installing, etc. The final goal of this phase is to make sure the ERP system can operate accurately. This phase also can be considered as the actually physical implementation phase.

In the Post-implementation phase, the ERP system is born officially and begins to integrate into the routine. The members of the organization will study to familiar with the ERP system accompanied by debugging and maintaining. ERP will start to bring value to the organization. There also will be countless minor-upgrade and irreversible decline due to the development of the technology and the organization itself.

It is clear that the third phase is the appropriate period as the real ERP Life Cycle. The period before the operation should be thought as the ERP Realization. The traditional concept of ERP Life Cycle should be considered as the ERP Implementation Course.

Tingting Huang and Kazuhiko Yasuda (2016), Journal of Enterprise Resource Planning Studies, Article ID 331270, DOI: 10.5171/2016.331270 


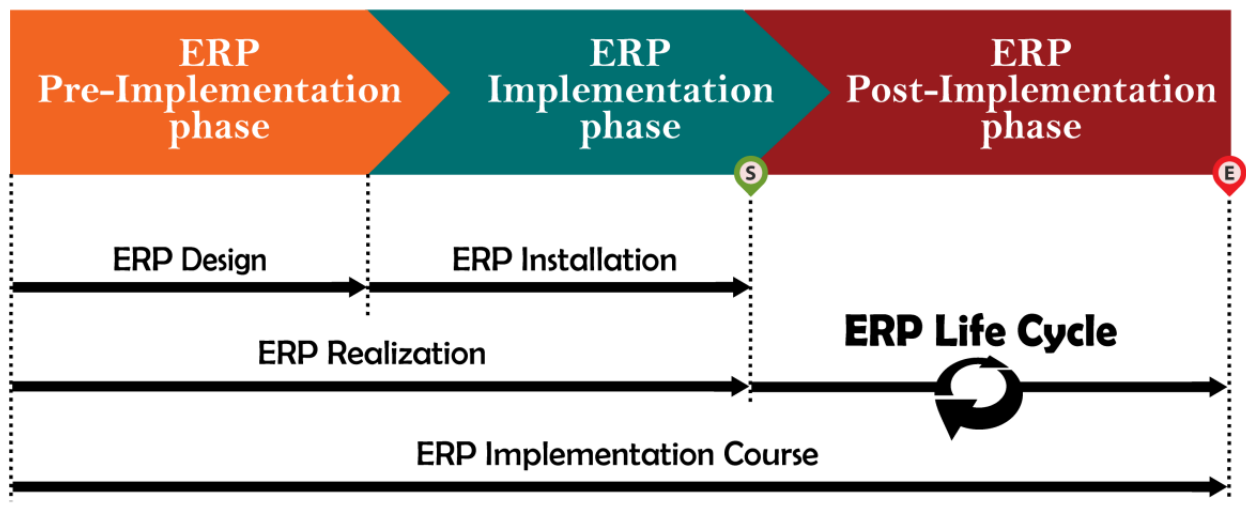

(5) Go-Live / Cut-Over / Roll-Out

(E) Withdraw / Retire / Replace / Change / Decommision

Figure 1: Rethinking ERP Life Cycle

\section{Reinventing ERP Life Cycle Model}

After redefining the term of 'ERP Life Cycle, we find it is necessary to build a conceptual model of ERP Life Cycle in order to transform abstract conceptions into concrete images. To answering the following question, that is "How many stages are usually there during the ERP Life Cycle, and how to divide it?", we take two different perspectives. Let's take a look at the prior studies first.

\section{Regular Patterns in Previous Studies}

Among the 26 original models that we selected, there are 9 models (Bento and Costa, 2013; Brehm and Markus, 2000; Dibbern et al., 2002; Kumar and Gupta, 2011; Law, Chen and $\mathrm{Wu}, 2010$; Markus and Tanis, 2000; Peslak, Subramanian and Clayton, 2007; Shanks et al., 2000; Souza and Zwicker, 2009) that have 2 stages during the post-implementation phase; 11 models (Ahituv et al., 2002; Aloini et al., 2007; Bajwa et al., 2004; Chang and Gable, 2000; Dantes and Hasibuan, 2011; Ehie and Madsen, 2005; Hasibuan and Dantes, 2012; Parr and
Shanks, 2000; Rosemann, 2000; Shields, 2001; Stefanou, 2001) that do not have partitions; 4 models (Esteves and Pastor, 1999; Klee, 2005; Mäkipää, 2003; Ross, 1998) that have 3 stages or more, and there are also 2 models (Alizai and Burgess, 2010; Bancroft, 1996) that do not cover the last phase.

Based on the analysis, two stages that most models have shown focus on are the stabilizing (use, termination, operation...) stage and the improving (evolution, enhancement, development...) stage. Between them, the stabilizing stage is mentioned by most of the 24 models. The declining (retirement...) stage, which seems has no data support, is used by 3 models and discussed by others. However, this stage will definitely come, and it should not be considered as a bad sign. For starters, the definition of Life Cycle that we have already discussed means there must be an end to finish the cycle. In despite of the wishes that organizations should live forever, they die eventually in different ways. Plus, the decline of ERP system also can indicate the new technology's coming, the new 
development of management strategy, and the transformation of organizations. Hence, the decline stage should be covered as the first two stages too.

There is also one stage-tends to be treated as one of the implementation phase in most models-is mentioned, the stage behind the Go-Live and before the stabilizing stage. With a little common sense, any new system, especially the large and complicated ERP system, will not become stable just after the switch is turned on for the first time. There should be a period of time for system to be adjusted in order to fit the business, and for people to adopt the new working way. All in all, four-stage model seems can describe the ERP Life Cycle better. To get a deeper understanding, we will discuss it from another perspective.

\section{Dynamics in Organizations}

By looking at the classical Product Life Cycle (PLC) theory, we can understand that any PLC begins at the time when the products ware launched into the market for the first time, and then ends at the time when the products will be gone out from the market eventually. Typically the life variation of most products can be illustrated as a bell-shape curve according to some indicators such as sales or sales volume. By observing the PLC curve carefully, we can recognize some distinct stages along the PLC curve line. Usually there are four or five stages during PLC duration.

As discussed earlier, the ERP Life Cycle in organization nowadays indicates the time span from Go-Live to Withdrawal.
In order to systematically view the life variation of ERP system during ERP Life Cycle, we should learn to know or rationally speculate what is really happening first. By using proper indicators, the life variation of ERP system can be reproduced, and also the distinct stages can be divided.

Hence, a practical procedure for reinventing the conceptual model of ERP Life Cycle is as follows:

Step 1: Setting proper indicators of life variation of ERP system,

Step 2: Analyzing the variation of each indicator during the whole time span of ERP,

Step 3: Identifying the critical points to divide distinct stages, and

Step 4: Naming the stages each, and reclassifying the characteristics of each stage.

\section{Five criteria}

Indeed, very few academics have illustrated the variation of ERP Life Cycle into graph as successful as PLC (Product Life Cycle). In order to illustrate ERP Life Cycle, Aloini et al., (2007) chose one indicator that is "Recourse", and Costa and Aparício (2005) used "Benefits". Both figures of ERP Life Cycle have the similar shape as PLC but with fewer explains and more ambiguity. The main reason that we do not have an accepted graph of ERP Life Cycle is because that the life variation of ERP system in organization is too complicated for one single indicator to handle. As a matter of fact, neither the organization's performance nor the ERP system's performance alone can represent ERP Life Cycle

Tingting Huang and Kazuhiko Yasuda (2016), Journal of Enterprise Resource Planning Studies, Article ID 331270, DOI: 10.5171/2016.331270 
integrally. Hence, we try to use multiple indicators instead. One indicator may be qualitative and subjective, but it can reflect variation of one relevant part; selecting the right and enough indicators can combine the parts and puzzle out the whole picture.

Since two decades ago, the way of dealing with the relationship between business and Information Technology / Information Systems (IT/IS) has been the focus of world's attention. There are numerous researches both conceptual and empirical. Henderson and Venkatraman (1993) proposed the Strategy Alignment Model (SAM) which estimates the alignment from two dimensions, strategic fit and functional integration. Business strategy, IT strategy, Organizational infrastructure and processes, and IT infrastructure and processes were recognized as four dynamics of the model, and the interactions between them were categorized as four alignment perspectives which organizations should have a great think before choosing any of them. Meanwhile, Lederer and Mendelow (1989) suggested three linkages-content, timing and personnel-to achieve the coordination between IS plan and business plan. Reich and Benbasat (2000) also paid attention to the dimension of personnel. Shared Domain Knowledge between business and IT executives was considered to be the only one factor that will affect the long-term alignment. Another famous researcher, Luftman (2000), proposed the model of assessing business-IT alignment maturity, and used the model to evaluate 25 firms successfully.
In order to stress the distinction of each stage of ERP Life Cycle, we identify two major dimensions consist of five criteria which are considered to represent the condition during ERP Life Cycle based on the above prior researches. The first dimension is the performance of the organization related to the ERP system, which consists of three criteria; they are Governance, Participation, and Skills. The second dimension is the performance of the ERP system itself, which consists of two criteria; they are Cost Efficiency, and Scope \& Architecture. In addition, all criteria are interrelated and interact on each other.

(1) Governance: This criterion represents the ability and willingness to manage, plan, and use the resources to achieve the goal of introducing an ERP system into the organization. Continuous Improvement, Budgetary Control, and Adaptability can be used to verify the alteration of the Governance. Continuous Improvement represents the management strategy of improvement in both operation and technique. Budgetary Control is the execution status of the budget plan of ERP system. The Adaptability means the ability of management to adjust unpredictable variation from outside or inside the organization.

Basically, the Governance rises from the bottom if the organization has no experiences on managing an ERP system. The budgetary control will be hard in the beginning, which has been proved by many cases that most of ERP projects ended to be out of control. Meanwhile, the Adaptability and

Tingting Huang and Kazuhiko Yasuda (2016), Journal of Enterprise Resource Planning Studies, Article ID 331270, DOI: 10.5171/2016.331270 
Continuous Improvement will keep growing for a long time, and ideally hit the top and keep it as long as possible. Just like the organization itself, although every entity is supposed to exist forever, they will transform, such as dead, amalgamation, or being taken over, in the end. The Governance will decline after all. So, three main stages can be conducted, that are the first stage with a fast raising rate, the stable stage, and the decline stage.

(2) Participation: "Personnel" is pointed out as a major factor that has important effect on the alignment of business and IT/IS (Lederer and Mendelow, 1989; Reich and Benbasat, 2000). However, the participation of people in the organization is more essential. Any perfect process/system will become a junk if no one has the Willingness to use it. Similarly, the Efficiency and the Frequency will also reflect the alteration of this criterion. The users of an ERP system consists of all relevant groups, such as the employees inside the organization, the co-operative corporations in the supply chain, the support group, customers, and so on. The rules may conduct the result of the Efficiency and the Frequency. But the willingness which needs digging a little bit harder can truly reflect this criterion.

This criterion seems like the organizational culture, which means it needs the right rules and the smart way to get things done. Appropriate training and efficient process design will be two major factors that affect the Participation. There will be three stages to express the variation of this criterion. At first, it will raise in the max speed due to training. Although the Willingness of users may be high before the Go-Live since most of people are exiting about change, the output of users' the first day job with new system cannot be good. Sooner or later, users will adapt the new way of doing things, which leads to the second stage. As same as the Governance, the decline stage will come for the following reasons. For starters, the resist emotion will emerge when the gap between business process and ERP system process grows. Especially, when new business process and needs have been adopted, but the ERP system is still running without appropriate system patch in time. Another situation will be the bad functional experience, such as obsolete hardware and software. It has three stages too.

(3) Skills: Skills include the business skills, the IT skills, and the communicational skills between them. It has the same user groups with the second criterion, Participation. Hence, the three major factors of this criterion are the Business-IS (Information Systems) Understanding, the Efficiency of Training, and the Knowledge Sharing. The Business-IS Understanding means the level of users' acknowledges both in business and ERP system. The Efficiency of Training represents the quality of the organization's training strategy. The Knowledge Sharing is as same as the consciousness of sharing their knowledge with others individually.

The Skills represents the quality of users and also the effort that organization makes on aligning the ERP system with the business. The variation

Tingting Huang and Kazuhiko Yasuda (2016), Journal of Enterprise Resource Planning Studies, Article ID 331270, DOI: 10.5171/2016.331270 
is based on the growth rate of this criterion. There will three levels. They are the fastest-growing level, the growing level, and the static level. Since it is a cumulative process, the decline stage rarely appears which means there are only two major stages.

(4) Cost Efficiency: As one of the two criteria that express the performance of the ERP system, the Cost Efficiency is also the most important criterion of all. There are three considerable aspects that may cause the major costs, the Operation, the Maintenance, and the Support. As long as the ERP is running, the costs from the three aspects are unavoidable. Since a smaller cost may not bring a bigger benefit, the efficiency of a cost is considered to be more appropriate than cost.

Esteves et al., (2002) suggested identifying the total costs associated with the ERP systems during the whole life cycle. The costs were classified into tangible costs and intangible costs, and all the possible costs were listed in each stages of their ERP life cycle model. A case study also was described as an example, but only the first four stages were covered. In our study, the essential is not to evaluate how many costs have been spent in each stage but how efficiency the costs have been, and also the variation of the cost efficiency from one stage to another. According to the above analyses, the disordered initial status of an ERP system will leads to the low cost efficiency. This stage will also be a stage with the highest raising rate of Cost Efficiency, and follows by a stage with average raising rate of Cost Efficiency. Unlike the other criteria, the Cost Efficiency is very sensitive with the variation of organization and system. This means the criterion will alternate when changes come. The changes consist of business reengineering, system improvement and so on. In the long term, when the Cost Efficiency is dropping, whether fast nor slowly, the decline stage comes. Four stages are considered to exist.

(5) Scope \& Architecture: This criterion represents the relationships between the business and information system in both the scope and the architecture. For instance, how many business processes in one department have been integrated in the ERP system or how many departments that the ERP system covers; the ability to adapt variation; and the ability to integrate. These can be conducted as the Coverage Scope, the Flexibility, and the Architectural Integration.

The initial stage is decided by the implementation strategy, such as the Big Bang, the Franchising strategy, the Slam dunk, and the on-Demand Nibble (Koch et al., 1999). The same scope and architecture will not vary until the stage with changes mentioned above comes. Along with the obsoleting of the ERP system, the same decline with a slower rate will arrive. Three stages can be identified.

\section{Three critical points}

According to the above analyses, three critical points which stages change from one to another can be conducted.

(1) The Stabilization point. All the criteria except the Scope \&

Tingting Huang and Kazuhiko Yasuda (2016), Journal of Enterprise Resource Planning Studies, Article ID 331270, DOI: 10.5171/2016.331270 
Architecture have a fastest-growing stage. When this stage ends, a relative stable stage will begin. The point between these two stages is called the Stabilization point.

(2) The Transformation point. In the Cost Efficiency and the Scope \& Architecture, we discussed the stage that may carry many changes. It happens behind the stable stage. The first step of evolution is called the Transformation point.

(3) The Turing point. Without the Skills, other four criteria will experience the clear decline stage. The Turing point is the beginning of the dropping.

All in all, the same result can be obtained. A comprehensive ERP Life Cycle model which contains all three critical points and covers all stages of every dimension should consist of four stages (Figure 2). We will explain the four-stage model of ERP Life Cycle specifically in the next section.

\section{Conceptual Model of ERP Life Cycle}

We propose a new conceptual model of ERP Life Cycle (Figure 2). It consists of four main stages, which are the Diffusion stage, the Utilization stage, the Enhancement stage, and the Decline stage.

\section{The Stages of the Conceptual Model of} ERP Life Cycle

As a stage model, it is important to define the transitional points and the clear events of each stage. Meanwhile, the naming of each stage is also very essential since it reflects the angles that examining the matter from. As we can see in the previous studies, the naming in the pre-implementation phase such as "Adoption Decision", "System Selection", and "Acquisition", presents the statues of the organization which is going to adopt an ERP system, due to the fact that ERP system is not exist yet. However, in the post-implementation phase, the naming such as "Stabilization", "Maintenance", and "Improvement", tends to express only the situation of the ERP system. Hence, it is necessary to naming with balance as much as possible. In our model, there are two dimensions behind the naming of the four-stage model, which reflect the status of the ERP system and the performance of the organization. This will be explained specifically in the next section.

In this section, each stage will be described briefly and compared with the previous models specifically in the following to get a better understanding. The characteristics of each stage will be discussed precisely in the next section.

Tingting Huang and Kazuhiko Yasuda (2016), Journal of Enterprise Resource Planning Studies, Article ID 331270, DOI: 10.5171/2016.331270 


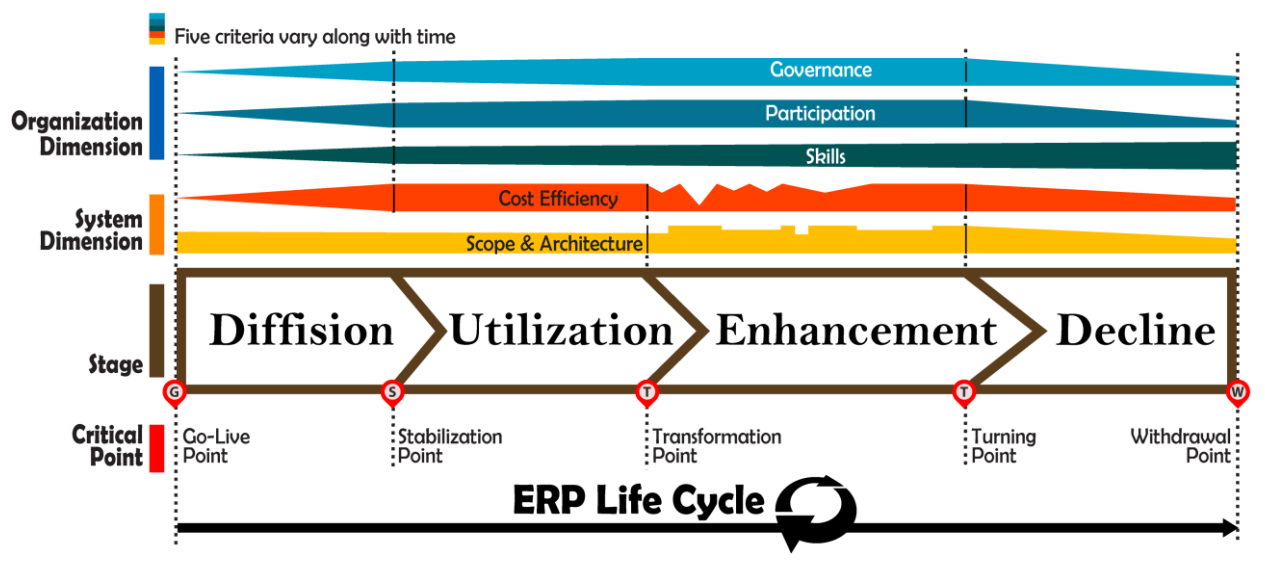

Figure 2: Conceptual Model of ERP Life Cycle

The Diffusion stage: This period starts at the Go-Live point, which means the staffs can recognize and use the ERP system through their computers, and ends at the Stabilization point. This stage was usually considered to be one part of the Implementation phase (Ahituv et al., 2002; Aloini et al., 2007; Bajwa et al., 2004; Bento and Costa, 2013; Dibbern et al., 2002; Esteves and Pastor, 1999; Parr and Shanks, 2000; Rosemann, 2000; Ross, 1998; Shanks et al., 2000; Shields, 2001; Stefanou, 2001).There are also some researches which have the same stage with different name (Brehm and Markus, 2000; Klee, 2005; Kumar and Gupta, 2011; Mäkipää, 2003; Markus and Tanis, 2000; Souza and Zwicker, 2009). Few researches integrated this stage into the post-implementation phase (Dantes and Hasibuan, 2011; Ehie and Madsen, 2005; Hasibuan and Dantes, 2012; Law et al., 2010; Peslak et al., 2007).

The Utilization stage: This stage is expected to begin once the performance reaches its first steady state. Staffs can use the ERP system as any other usual software. This period was also one of the most recognized periods. Esteves \& Pastor used "Use \& Maintenance" (Esteves and Pastor, 1999). Many defined it as "Stabilizing" (Dibbern et al., 2002; Ross, 1998; Shanks et al., 2000). Andy Klee (2005) chooses the word "Extending Value", and Mäkipää (2003) used “Termination”. Stefanou (2001), Ahituv et al., (2002) and Bajwa et al., (2004) summarized this stage with the following stages as "Operation". Some did not prepare minor stages (Aloini et al., 2007; Bento and Costa, 2013; Brehm and Markus, 2000; Chang and Gable, 2000; Dantes and Hasibuan, 2011; Ehie and Madsen, 2005; Hasibuan and Dantes, 2012; Kumar and Gupta, 2011; Law et al., 2010; Markus and Tanis, 2000; Parr and Shanks, 2000; Rosemann, 2000; Shields, 2001; Souza and Zwicker, 2009).

The Enhancement stage: Accompanied by the first reform action, this stage comes. People are familiar with the ERP system and try to explore more value about it. We can find many definitions 
about this stage: "Evolution" (Esteves and Pastor, 1999), "Improvement" (Shanks et al., 2000; Shields, 2001), "Operation \& Improvement" (Dibbern et al., 2002), "Exploitation and Development" (Mäkipää, 2003), "Maintaining Value" (Klee, 2005), "Maintenance" (Peslak et al., 2007), and "Integration" (Law et al., 2010). Ross (1998) used two stages "Continuous Improvement" and "Transformation" to describe this process, and others used one long stage that contains it (Ahituv et al., 2002; Aloini et al., 2007; Bajwa et al., 2004; Bento and Costa, 2013; Brehm and Markus, 2000; Chang and Gable, 2000; Dantes and Hasibuan, 2011; Ehie and Madsen, 2005; Hasibuan and Dantes, 2012; Kumar and Gupta, 2011; Markus and Tanis, 2000; Parr and Shanks, 2000; Rosemann, 2000; Souza and Zwicker, 2009; Stefanou, 2001).

The Decline stage: The final stage will happen when the current system cannot reach higher level; meanwhile the rate of use starts to dropping due to many reasons, such as management process reform or equipment obsolescence. There were little reaches referred to this stage. The most quoted is the "Retirement" stage of Esteves and Pastor (1999). Klee (2005) called this stage as "Declining Value", and also Bento \&Costa (2013); Ahituv et al., (2002) did not name this stage separately, but this period was contained into the Operation stage.

The comprehensive comparison between the conceptual model and prior models of traditional ERP Life Cycle is summarized in the Table 1.

\section{The Characteristics of Conceptual Model of ERP Life Cycle}

To discuss the characteristics of the proposed model, based on the prior researches, we chose eight key elements that are considered to be appropriate. They are five major criteria, Governance, Cost Efficiency, Scope \& Architecture, Participation and Skills. Others are Starting point, Ending point, and expected Time span (in theory) (Table 2).

The Diffusion stage: During this stage, one of the significant activities that previous scholars almost have pointed out is user training. Since a major organizational change usually is introduced into organization along with the new system, the user training should not only on technology but also on new processes and contexts (Ross, 1998). The performance of users will increase rapidly due to the centralized training of staffs, since all the other criteria are prepared during the implementation phase, the Participation and the Skills can be affected heavily by training. Contrarily, the output of the ERP system is bad with the lowest efficiency and highest errors in both system and business operation, which means the Governance and the Cost Efficiency will be hard to control. This is the main reason why ERP system will not reach the highest level, although the organization may set the Scope \& Architecture highly, and have a perfect training plan.

Everything in this stage is hectic and confusing (Mäkipää, 2003; Shields, 2001), people need a lot of support in the days immediately after beginning to

Tingting Huang and Kazuhiko Yasuda (2016), Journal of Enterprise Resource Planning Studies, Article ID 331270, DOI: 10.5171/2016.331270 
use a new system (Shields, 2001). That's because users with not enough awareness at the beginning are strange to the system, usually there will be a conflict emotion. Hence, maintenance and user training are necessary in this stage, and also consultants' support. It is a stage in which problems that could not have been easily detected at the implementation phase become apparent, and the exact characterization of this stage is related to the operation starting mode chosen by the company (Souza and Zwicker, 2009). Dantes and Hasibuan (Dantes and Hasibuan, 2011) suggested using two levels, process and technology, to categorize the activities; one new activity that should start from the beginning of the post-implementation phase is evaluation and audit system. This stage begins from Go-live point which means ERP system starts to operation formally to Stabilization point that ERP system reaches the first stabilizing. This period is expected to be shorter the better. In fact, thanks to the popularization and development of IT technology, this stage should be shorter than before, and the theoretical time span is $3 \sim 6$ months.

The Utilization stage: When the system first reaches the stabilization point, the Utilization stage comes. The stabilization point indicates the initial aims of the ERP system have been accomplished. Ross found out there was a period of stabilization immediately following the implementation phase; the process of cleaning up the data led to significant improvements in understanding firms' products and processes (Ross, 1998). The project team is being pulled down and team members are being relocated or back located (Mäkipää, 2003), and establishment of support centers is looked forward to (Ahituv et al., 2002). The consultants' support gets fewer than before, and most users feel adapted, there will even be some exploration actions appear. All of these mean the knowledge and the experiences are increasing; every criterion is prepared for the next stage. The Governance is better than the first stage but not good enough; the Cost Efficiency is considered to increase fast. The expected benefits of the system are considered to return from this stage (Esteves and Pastor, 1999). It is worthwhile to note the variation of the Participation. Although the Skills reach the goal, the Participation will reflect the design of the architecture both in business and IS. If the willingness and frequency of using the IS are low, it is necessary to verify the process again.

When new needs appear during the operation or a small design defect, in other words, the business process and the current ERP system cannot be satisfied with each other, the third stage will come. On the other hand, when there is an upgrade plan about the system, the same thing will happen too. In any case, the reform action will put this stage into end. Reform represents upgrade and replace partly, which is companied by changes in the system that need new training for users. The performance will begin to vary, that can be recognized as transformation point. The theoretical time span is $1 \sim 2$ years.

The Enhancement stage: This stage consists of improvement situation and

Tingting Huang and Kazuhiko Yasuda (2016), Journal of Enterprise Resource Planning Studies, Article ID 331270, DOI: 10.5171/2016.331270 
stabilization situation will occur repeated during this period that is considered to be the longest time span, $5 \sim 10$ years. Organizations start to generate significant operating benefits and add functionality through new modules or bolt-ons, in other words, the process orientations begin (Ross, 1998; Stefanou, 2001). This stage corresponds to the integration of more capabilities into the ERP system, providing new benefits from ERP maturity both operational and strategic (Ahituv et al., 2002; Aloini et al., 2007; Esteves and Pastor, 1999; Parr and Shanks, 2000; Rosemann, 2000; Souza and Zwicker, 2009; Stefanou, 2001). However, these "typical" activities may not performed if the knowledgeable personnel who understand the rationales for prior configuration choices and how to improve the business processes through the use of the system are lost (Markus and Tanis, 2000).

After the first two stages, the Governance and Cost Efficiency have reached high level in the Enhancement stage. This also presents that the organization has the ability to improve both in business and IS. The Scope \& Architecture will be alteration, because of the implementation strategy. Ideally, the performance should reach the highest level and keep it up in theory. However, the failed reform will also be possible, and the performance will decrease temporarily. Hence, this stage will present as a long shock period.

The users are already familiar with the system, many applications and innovations around the system are considered to appear frequently.
Sometimes it is best to require the users to make do with the system they have before deciding what additional functionality is really required (Shields, 2001). Bajwa et al., (2004) named this phenomenon as Organization learning. Shields (2001) also suggested to pay attention to ERP users' and Partners/customers' satisfaction. Meanwhile, there will be high efficiency and little error about the system performance. The business performance is considered to keep rising in the mass. Additionally, with the high level of the Participation and the Skills, the performance trends to reach balance point quickly after every improvement. Besides, the vendor normally will release upgrades in order to fix bugs, to add new functionality and/or include changes necessitated by external factors (Brehm and Markus, 2000).

It is noteworthy that there will be an irreversible dropping situation appears in criteria. There will be many reasons, such as large scale rearrangement on management process or organizational structure, and large scale obsolescence of equipment and technology. Usually, this phenomenon appears in the Cost Efficiency. When this happens, the final stage will occur. This point is called Turning point.

The Decline stage: If we draw the graph, the curve of the Decline stage should be just the curve of the initial stage that is flipped horizontally. When the ERP no longer responds to the company's challenges, and the appearance of new technologies or the inadequacy of the ERP system or approach to the business needs (Ahituv

Tingting Huang and Kazuhiko Yasuda (2016), Journal of Enterprise Resource Planning Studies, Article ID 331270, DOI: 10.5171/2016.331270 
et al., 2002; Bento and Costa, 2013; Esteves and Pastor, 1999). The performance drops quickly; the needs of organization cannot be satisfied although the system itself has little errors. The users will begin to complaint about the system, and new arrangement will be scheduled gradually. Upgrading is now nearly as costly as implementing a new ERP solution (Bento and Costa, 2013; Klee, 2005), the current system will be reformed completely in the end which can be recognized as the Withdrawal point. However the high costs inherent in the updating ERP's process is certainly also an opportunity to evaluate other vendors and other technologies (Bento and Costa, 2013). The theoretical time span is $1 \sim 3$ years. The support from the third party increase and the consultants' support will be more important if facing changing vendors. When the organization cannot recognize this phenomenon, this stage may be last long, and causes unexpected loss; when the organization already has a reform plan, this stage will be the period of preparing for the next ERP system.

Table 2: Characteristics of Each Stage of the ERP Life Cycle

\begin{tabular}{|c|c|c|c|c|c|}
\hline \multirow{2}{*}{\multicolumn{2}{|c|}{$\begin{array}{c}\text { Critical } \\
\text { Characteristics }\end{array}$}} & \multicolumn{4}{|c|}{ ERP Life Cycle } \\
\hline & & Diffusion & Utilization & Enhancement & Decline \\
\hline \multirow{3}{*}{ Govemance } & $\begin{array}{l}\text { Contimuous } \\
\text { Improvement }\end{array}$ & none & little & many & little \\
\hline & Budgetary Control & hard & easy & easy & hard \\
\hline & Adaptability & rising fast & rising slowly & high & $\begin{array}{l}\text { dropping } \\
\text { slowly }\end{array}$ \\
\hline \multirow{3}{*}{ Cost Efficiency } & Operation & \multirow{3}{*}{ rising fast } & \multirow{3}{*}{ rising slowly } & \multirow{3}{*}{ alternation } & \multirow{3}{*}{$\begin{array}{l}\text { dropping } \\
\text { slowly }\end{array}$} \\
\hline & Support & & & & \\
\hline & Maintenance & & & & \\
\hline \multirow{3}{*}{$\begin{array}{c}\text { Scope \& } \\
\text { Architecture }\end{array}$} & Coverage Scope & \multirow{3}{*}{$\begin{array}{l}\text { due to the } \\
\text { implementation strategy }\end{array}$} & \multirow{3}{*}{ same } & \multirow{3}{*}{ alternation } & \multirow{3}{*}{$\begin{array}{l}\text { dropping } \\
\text { slowly }\end{array}$} \\
\hline & Flexibility & & & & \\
\hline & $\begin{array}{l}\text { Architectural } \\
\text { Integration }\end{array}$ & & & & \\
\hline \multirow{3}{*}{ Participation } & Willingness & \multirow{3}{*}{$\begin{array}{l}\text { influenced heavily by } \\
\text { the training }\end{array}$} & \multirow{3}{*}{$\begin{array}{l}\text { reflect the rationality of } \\
\text { process design }\end{array}$} & \multirow{3}{*}{ high } & \multirow{3}{*}{$\begin{array}{l}\text { dropping } \\
\text { slowly }\end{array}$} \\
\hline & Efficiency & & & & \\
\hline & Frequency & & & & \\
\hline \multirow{3}{*}{ Skills } & $\begin{array}{c}\text { Business-IS } \\
\text { Understanding }\end{array}$ & & \multirow{3}{*}{ average } & \multirow{3}{*}{ high } & \multirow{3}{*}{ high } \\
\hline & $\begin{array}{l}\text { Efficiency of } \\
\text { Training }\end{array}$ & rising fast & & & \\
\hline & Knowledge Sharing & low & & & \\
\hline \multicolumn{2}{|c|}{ Starting point } & Go-Live point & Stabilization point & Transformation point & Turning point \\
\hline \multicolumn{2}{|c|}{ Ending point } & Stabilization point & Transformation point & Turning point & $\begin{array}{l}\text { Withdrawal } \\
\text { point }\end{array}$ \\
\hline \multicolumn{2}{|c|}{ Time peiciod } & $3 \sim 6$ months & $1 \sim 2$ years & $5 \sim 10$ years & $1 \sim 3$ years \\
\hline
\end{tabular}

\section{Conclusion and Future Works}

Nowadays, ERP has a high correlation with organizations, not just in some particular sections but through the entire management core. However, there is no guarantee that any organization can implement an ERP system once forever. The technology development, the environmental variation, and the transformation of organizations will all have potential impact on the ERP system eventually. In fact, we still have little acknowledge about the end of ERP system. Additionally, "case by case" is not a responsible solution when organizations are going to face above

Tingting Huang and Kazuhiko Yasuda (2016), Journal of Enterprise Resource Planning Studies, Article ID 331270, DOI: 10.5171/2016.331270 
problem. As our intention is to understand the variation of ERP system in organizations throughout ERP Life Cycle, the outcome will achieve the ability to predict the tendency of the operation status of ERP and give the organizations enough time to prepare for the future.

In this paper, we are trying to drag the attentions from pre-implementation phase and implementation phase to the post-implementation phase-the real ERP life cycle. We defined the term of ERP Life Cycle based on the new concept of Life Cycle, and proposed the conceptual model of ERP Life Cycle which consists of four stages: Diffusion, Utilization, Enhancement, and Decline. Although two dimensions and five criteria are proposed, to verify and revise the conceptual model of ERP Life Cycle, we should keep focusing and analyzing every stage of the ERP Life Cycle model, by collecting and studying the data from the organizations and consultants, and identify more critical factors that indicates the relationship between ERP system and the organization. Especially, the final stage which has no data should be paid more attentions to. Further, a more specific framework based on our conceptual ERP life cycle model for addressing research issues will be our main focus. It will be the basis of the researches on ERP post-adoption and be valued to both academic and practical world.

\section{References}

1. Ahituv, N., Neumann, S. and Zviran, M. (2002), 'A system development methodology for ERP systems,' Journal of Computer Information Systems, 43 (2), 56-67.
2. Alizai, F. and Burgess, S. (2010), An ERP adoption model for midsize businesses, Enterprise information systems: Concepts, methodologies, tools and applications, Cruz-Cunha, M. M., (ed.), British Library Cataloguing, London.

3. Aloini, D., Dulmin, R. and Mininno, V. (2007), 'Risk management in ERP project introduction: Review of the literature,' Information \& Management, 44 (6), 547-567.

4. Bajwa, D. S., Garcia, J. E. and Mooney, T. (2004), 'An integrative framework for the assimilation of enterprise resource planning systems: phases, antecedents, and outcomes,' Journal of Computer Information Systems, 44 (3), 81-90.

5. Bancroft, N. H. (1996), Implementing SAP R/3, Prentice Hall PTR, Greenwich.

6. Bento, F. and Costa, C. J. (2013), 'ERP measure success model: A new perspective,' Proceedings of the International Conference on Information Systems and Design of Communication, ISDOC '13, July 11-12, 16-26.

7. Brehm, L. and Markus, M. L. (2000), 'The divided software life cycle of ERP packages,' Proceedings of the 1st Global Information Technology Management World Conference, June 11-13, 43-46.

8. Catersels, R., Helms, R. W. and Batenburg, R. (2010), 'Exploring the gap between the practical and theoretical world of ERP implementations: results of a global survey,' Proceedings of IV IFIP International Conference on Research and Practical Issues of Enterprise Information systems, 25-27.

Tingting Huang and Kazuhiko Yasuda (2016), Journal of Enterprise Resource Planning Studies, Article ID 331270, DOI: 10.5171/2016.331270 
9. Chang, S.-I. and Gable, G. G. (2000), ' Major issues with SAP financials in Queensland government,' Proceedings of the 2000 Americas Conference on Information Systems, 972-975.

10. Costa, C. J. and Aparício, M. (2005), 'Managing the information system Life cycle in construction and manufacturing,' Proceedings of World Academy of Science, Engineering and Technology, 143-147.

11. Dantes, G. R. and Hasibuan, Z. A. (2011), 'Enterprise Resource Planning implementation framework based on key success factors (KSFs),' UK Academy for Information System, Paper 13.

12. Davenport, T. H. (1998), 'Putting the Enterprise into the Enterprise System,' Harvard Business Review, 76 (4), 121-131.

13. Deloitte Consulting (1999), ERP's second wave: Maximizing the value of ERP-enabled processes.

14. Dibbern, J., Brehm, L. and Heinzl, A. (2002), 'Rethinking ERP-outsourcing decisions for leveraging technological and preserving business knowledge,' Proceedings of the 35th Annual Hawaii International Conference on System Sciences, 2770-2780.

15. Ehie, I. C. and Madsen, M. (2005), 'Identifying critical issues in enterprise resource planning (ERP) implementation,' Computers in Industry, 56 (6), 545-557.

16. Esteves, J. M. and Pastor, J. A. (1999), 'An ERP life-cycle-based research agenda,' Proceeding of First International workshop in Enterprise Management and Resource Planning: Methods, Tools and Architectures, 359-371.
17. Esteves, J. M., Carvalho, J. and Santos, A. (2002), Towards an ERP life-cycle costs model, Enterprise resource planning solutions and management, 51-62.

18. Harada, T. (2008), 'The IT investment reaches peak in 2007, and the real life span of system is different from vendors' expectation,' Nikkei Computer(written in Japanese), 126-133.

19. Hasibuan, Z. A. and Dantes, G. R. (2012), 'Priority of Key Success Factors (KSFS) on Enterprise Resource Planning (ERP) system Implementation Life Cycle,' Journal of Enterprise Resource Planning Studies, 1-15.

20. Henderson, J. C. and Venkatraman, N. (1993), 'Strategic alignment: leveraging information technology for transforming orgnizations,' Reprinted From IBM Systems Journal, 32 (1), 472-484.

21. Holland, C. P. and Light, B. (1999), 'A critical success factors model for ERP implementation,' Software, Institute of Electrical and Electronics Engineers, 16 (3), 30-36.

22. Huang, T. and Yasuda, K. (2014), 'ERP Life Cycle Models: An Annotated Bibliographic Review,' Proceedings of the 15th Asia Pacific Industrial Engineering and Management Systems Conference, October 12-15.

23. Jacobs, R. F. and 'Ted' Weston Jr, F. C. (2007), 'Enterprise resource planning (ERP)-A brief history,' Journal of Operations Management, 25 (2), 357-363.

24. Kelle, P. and Akbulut, A. (2005), 'The role of ERP tools in supply chain information sharing, cooperation, and cost optimization,'

Tingting Huang and Kazuhiko Yasuda (2016), Journal of Enterprise Resource Planning Studies, Article ID 331270, DOI: 10.5171/2016.331270 
International Journal of Production Economics, 93-94 (2005), 41-52.

25. Kiadehi, E. F. and Mohammadi, S. (2012), 'Cloud ERP: Implementation of enterprise resource planning using cloud computing technology,' Journal of Basic and Applied Scientific Research, 2 (11), 11422-11427.

26. Klee, A. (2005), 'The ERP life cycle from birth to death and birth again,' [Online], [Retrieved 25, March], http://bbs.vsharing.com/upload-files/90/9 02677_42114.PDF

27.Koch, C., Slater, D. and Baatz, E. (1999), 'The ABCs of ERP,' [Online], [Retrieved 25, March], http://www.mis.yzu.edu.tw/faculty/celeste /course/im322/ERP\%20stuff/ABCs\%20of \%20ERP.pdf

28. Kumar, A. and Gupta, P. C. (2011), 'Implementation of knowledge management To minimize ERP based system's failure of an organization: A survey,' International Journal of Research in Finance \& Marketing, $1(3), 55-66$.

29. Law, C. C. H., Chen, C. C. and Wu, B. J. P. (2010), 'Managing the full ERP life-cycle: Considerations of maintenance and support requirements and IT governance practice as integral elements of the formula for successful ERP adoption,' Computers in Industry, 61 (3), 297-308.

30. Lederer, A. L. and Mendelow, A. L. (1989), 'Coordination of information systems plans with business plans,' Journal of Management Information Systems, 6 (2), 5-19.

31. Luftman, J. (2000), 'Assessing business-IT alignment maturity,'
Communications of Association Information Systems, 4 (14), 1-50.

32. Mäkipää, M. (2003), 'Implementation of Enterprise Resource Planning System Theoretical research approach and empirical evaluation in two cases,' Proceedings of the 26th Information Systems Research Seminar.

33. Markus, M. L. and Tanis, C. (2000), The enterprise systems experience - from adoption to success, Framing the Domains of IT Research: Glimpsing the Future Through the Past, Zmud, R. W., (ed.), Cincinnati, OH.

34. O'Leary, D. E. (2000), Enterprise resource planning systems: systems, life cycle, electronic commerce, and risk, Cambridge university press, New York, USA.

35. O'Rand, M. A. and Kcreker, M. L. (1990), 'Concepts of the life cycle: Their history, meanings, and uses in the social sciences,' Annual Review of Sociology, 16 (1), 241-262.

36. Parr, A. and Shanks, G. (2000), 'A model of ERP project implementation,' Journal of Information Technology, 15 (4), 289-303.

37. Peslak, A. R., Subramanian, G. H. and Clayton, G. E. (2007), 'The phases of ERP software implementation and maintenance: A model for predicting preferred ERP use,' Journal of Computer Information Systems, 48 (2), 25-33.

38. Reich, B. H. and Benbasat, I. (2000), 'Factors that influence the social dimension of alignment,' MIS Quarterly, 24 (1), 81-113.

39. Rosemann, M. (2000), 'Using reference models within the enterprise resource planning lifecycle,' Australian Accounting Review, 10 (22), 19-30.

Tingting Huang and Kazuhiko Yasuda (2016), Journal of Enterprise Resource Planning Studies, Article ID 331270, DOI: 10.5171/2016.331270 
40. Ross, J. W. (1998), 'The ERP revolution surviving versus thriving,' 1-10.

41. Shanks, G. G., Parr, A. N., Hu, B., Corbitt, B. J., Thanasankit, T. and Seddon, P. B. (2000), 'Differences in critical success factors in ERP systems implementation in Australia and China: A cultural analysis,' Proceedings of the European Conference On Information Systems, 537-544.

42. Shields, M. G. (2001), E-Business and ERP rapid implementation and project planning, John Wiley \& Sons, New York.

43. Souza, C. A. and Zwicker, R. (2009), ERP systems' life cycle: An extended version, Encyclopedia of information science and technology.

44. Stefanou, C. J. (2001), 'A framework for the ex-ante evaluation of ERP software,' European Journal of Information Systems, 10 (4), 204-215.

45. Yasuda, K. and Huang, T. (2014), 'Review of the Concepts, Meanings, and Uses of the Life Cycle,' Proceedings of the 15th Asia Pacific Industrial Engineering and Management Systems Conference, October 12-15. 